\title{
Sharp-tailed Grouse (Tympanuchus phasianellus) population dynamics and restoration of fire-dependent northern mixed-grass prairie
}

\author{
Robert K. MURPhy ${ }^{1,2, *}$ and KAREN A. SMIth ${ }^{1,3}$ \\ ${ }^{1}$ United States Fish and Wildlife Service, Des Lacs National Wildlife Refuge Complex, Kenmare, North Dakota 58746 USA \\ ${ }^{2}$ Current address: Eagle Environmental, Inc., 12 Longview Road, Sandia Park, New Mexico 87047 USA \\ ${ }^{3}$ Current address: 8210 88th Street NW, Kenmare, North Dakota 58746 USA \\ *Corresponding author: murph@eagleenvironmental.net
}

Murphy, R.K., and K.A. Smith. 2019. Sharp-tailed Grouse (Tympanuchus phasianellus) population dynamics and restoration of fire-dependent northern mixed-grass prairie 133(3): 253-262. https://doi.org/10.22621/cfn.v133i3.2115

\begin{abstract}
Case studies of Sharp-tailed Grouse (Tympanuchus phasianellus) population dynamics before and during re-introduction of fire to northern mixed-grass prairies that lacked fire for multiple decades are unavailable. At a 108- $\mathrm{km}^{2}$ northern mixedgrass prairie refuge in North Dakota, fire was suppressed from the early 1900s through late 1970s. Nine management units (total area $16.8 \mathrm{~km}^{2}, 15.7 \%$ of the refuge) received initial prescribed fire treatments during 1979-1984. The mean annual density of male Sharp-tailed Grouse attending leks on these units during 1981-1985 $\left(9.0 \mathrm{males} / \mathrm{km}^{2}\right)$ was twice that on the same units during 1961-1965 (4.2 males $\left./ \mathrm{km}^{2}\right)$, amid the fire exclusion era; nonoverlap of $90 \%$ CIs encompassing the means suggested a significant treatment effect. However, densities of males on units managed without prescribed fire during 19611965 and 1981-1985 did not change between the two periods. By 1987, fire had been re-introduced to $>50 \%$ of the refuge overall. Mean annual abundance (i.e., total numbers) of lekking males on the entire refuge did not differ between 1961-1965 and 1981-1985 but was significantly greater during 1989-1993 than during 1961-1965 and 1981-1985. Changes in density and abundance of lekking males coincided with fire-induced reductions in woody cover and increases in herbaceous cover. Our study illustrates the marked capacity of Sharp-tailed Grouse to respond to reductions of tree and shrub cover resulting from prescribed fire in northern mixed-grass prairie and the species' attraction to habitat disturbance in general.
\end{abstract}

Key words: Sharp-tailed Grouse; Tympanuchus phasianellus; northern mixed-grass prairie; prairie management; prescribed fire; North Dakota

\section{Introduction}

During the 1900s, tree and shrub cover increased markedly on present-day national wildlife refuges in the northern mixed-grass prairie (NMGP) region of North America's Great Plains, mainly due to fire suppression (Grant and Murphy 2005). Fire-intolerant Trembling Aspen (Populus tremuloides Michaux), Silverberry (Elaeagnus commutata Bernhardi ex Rydberg), and Western Snowberry (Symphoricarpos occidentalis Hooker) were common tree and shrub species that proliferated. Some species of grasslanddependent passeriform birds that bred on the refuges became rare or absent in areas invaded by trees and shrubs (Madden et al. 1999; Grant et al. 2004; Murphy and Smith 2007). Sharp-tailed Grouse (Tympanuchus phasianellus), a conspicuous member of the NMGP breeding bird community, may abandon landscapes that become invaded by trees and shrubs in the absence of fire, e.g., in Aspen Parkland (Caldwell 1976;
Moyles 1981; Berger and Baydack 1992). However, there are no published reports of changes in numbers of the species during years encompassing prescribed fires to restore grassland landscapes invaded by woody vegetation in the NMGP region.

While compiling a case study on the management of $108-\mathrm{km}^{2}$ Lostwood National Wildlife Refuge (LNWR), centred in the NMGP region, we found that data on annual counts of Sharp-tailed Grouse and concurrent records of fire re-introduction to the area after roughly 60 years of fire exclusion could contribute to the knowledge of fire's role in Sharp-tailed Grouse management. Moreover, the case study could be supported by published data on changes in dominance of woody versus herbaceous vegetation associated with prescribed fire on the refuge (Madden et al. 1999; Murphy and Smith 2007; Smith and Murphy 2007) given a major refuge management objective: to restore the historic (before settlement by Euro- 
American peoples) balance of woody versus herbaceous vegetation to favour native grassland bird species and other native wildlife (U.S. Fish and Wildlife Service 1998). Our first study objective, carried out at a local spatial scale, was to compare the density (i.e., number $/ \mathrm{km}^{2}$ ) of lekking male Sharp-tailed Grouse on prairie management units during 1961-1965, amid the fire exclusion era, to the density of lekking males on the same units under initial prescribed fire treatments during 1981-1985. Our second study objective, pursued at a landscape scale, was to compare overall abundance (i.e., total number) of lekking male Sharptailed Grouse on all of LNWR among three 5-yr periods: (1) 1961-1965, amid the fire exclusion era; (2) 1981-1985, the initial fire re-introduction period; and (3) 1989-1993, after $>50 \%$ of the refuge had been treated by prescribed fire at least once. As part of this objective, we also examined relationships between abundance or density of lekking male Sharp-tailed Grouse and fire history, i.e., number of fires conducted, across management areas of the entire refuge.

\section{Methods}

LNWR, in Burke and Mountrail counties, northwestern North Dakota $\left(48.617^{\circ} \mathrm{N}, 102.450^{\circ} \mathrm{W}\right)$, is rolling to hilly native prairie (55\% of refuge area) and tame grasslands (21\%) interspersed with about 4000 , 0.1 - to 224-ha wetlands (20\%; Murphy 1993). Before settlement by Euro-Americans in the early 1900s, the upland landscape was mixed-grass prairie dominated by needlegrasses (Nassella viridula [Trinius] Barkworth, Hesperostipa comata Oldham and Brinker, Heterostipa spartea [Trinius] Barkworth), Western Wheatgrass (Pascopyrum smithii [Rydberg] Á. Löve), Blue Grama (Bouteloua gracilis [Kunth] Lagasca ex Griffiths), and a variety of native forb species (Barker and Whitman 1988). Shrubs probably covered $\sim 5 \%$ of the uplands and trees were rare (U.S. Soil Conservation Service 1975). Patches of tree-size Trembling Aspen began to appear by the 1930s (as detected in aerial photos) after 10-20 years of active fire suppression (Murphy 1993). The density and mean size of aspen patches on LNWR increased from 1.5 patches $/ \mathrm{km}^{2}$ and 0.13 ha in the mid-1930s, when the refuge was established, to 4.8 patches $/ \mathrm{km}^{2}$ and 0.36 ha in the early 1980 s, respectively. Shrub cover dominated by Western Snowberry increased from $25 \%$ in the mid-1930s to $>50 \%$ by the early 1980 s.

Counts of lekking male Sharp-tailed Grouse can yield reliable population indices if done within narrow constraints with bias accounted for (Drummer et al. 2011). All Sharp-tailed Grouse leks on LNWR were located systematically in early spring annually during 1961-1965 and 1981-1993, following standard guidelines (Kirsch 1956). Each lek had at least two males by definition. To maximize accuracy, males were counted two to four times on each lek between $0.5 \mathrm{~h}$ before sunrise to $2 \mathrm{~h}$ after sunrise during midApril through early-May, encompassing the peak period of lek attendance by breeding hens in the region (Connelly et al. 1998). Males on some leks could be counted by observation with binoculars from nearby hilltops. Most leks, however, were higher than their surroundings such that some or most males could not be viewed directly from any single location. In such a case, the observer crept to within $\sim 3-10 \mathrm{~m}$ of the lek's edge and listened to determine whether females were present; acoustic displays by male Sharp-tailed Grouse on leks are distinctly more intense when females are there (Connelly et al. 1998). If females were present, they would flush immediately when the observer stood slowly. In contrast, males typically hesitated to flush for several seconds after all females flushed, then flushed and flew together in a cohesive flock. The flocked males typically could be counted by the observer at least twice before landing or flying from view. The same procedure would be followed at the respective lek on at least one other morning until counts of total males on the lek were consistent among mornings.

To address our first objective of comparing the density of lekking male Sharp-tailed Grouse on management units during 1961-1965 to the density of lekking males on the same units during initial prescribed fire treatments $\sim 20$ years later, we used concurrent changes in densities of lekking males on units not prescribe-burned as a baseline for comparison. Relying on refuge records, we categorized the 19401985 management history of units as either (1) grazed by cattle $<19$ years; (2) grazed by cattle $>29$ years; (3) prolonged rest; (4) treated by prescribed fire during 1979-1984; or (5) burn perimeter (Table 1, Figure 1). Prescribed fires at LNWR were conducted by using a surround technique, described in Murphy and Smith (2007). Most fires consumed $>80 \%$ of aboveground vegetation (Table 2 ). We categorized the area within $0.8 \mathrm{~km}$ of burn units as burn perimeter (a mix of grazed $<19$ years, grazed $>29$ years, and prolonged rest categories; Figure 1) because prescribed fires could indirectly influence densities of lekking male Sharp-tailed Grouse on adjacent management units, and $0.8 \mathrm{~km}$ approximates the mean distance between the species' leks and nest sites (reviewed in Connelly et al. 1998).

We could not formally test for differences in density of lekking male Sharp-tailed Grouse among management history categories because management treatment types were not assigned randomly to the various units, and prolonged rest and burn perimeter categories were represented by only one and 
TABLE 1. Management history of prairie management units at Lostwood National Wildlife Refuge in northwestern North Dakota during 1940-1985.

\begin{tabular}{|c|c|c|c|}
\hline Unit category & $\begin{array}{l}\text { Number of } \\
\text { units }\end{array}$ & $\begin{array}{l}\text { Total area } \\
\left(\mathrm{km}^{2}\right)\end{array}$ & Management history description \\
\hline Grazed $<19$ years* & 3 & 13.8 & $\begin{array}{l}\text { Grazed by cattle at light stocking rates (0.4-0.6 Animal Unit Months/ha) } \\
\text { during July-October every } 1-4 \text { years during } 1940-1979 \text { and rested during } \\
\text { 1980-1985 }\end{array}$ \\
\hline Grazed $>29$ years $^{\dagger}$ & 3 & 16.0 & $\begin{array}{l}\text { Grazed by cattle at light stocking rates (0.4-0.6 Animal Unit Months/ha) } \\
\text { during July-October every 1-2 years during 1940-1979 and rested during } \\
\text { 1980-1985 }\end{array}$ \\
\hline Prolonged rest & 1 & 7.1 & Not grazed or prescribe-burned \\
\hline Burned 1979-1984 & 9 & 16.8 & $\begin{array}{l}\text { Rested and periodically grazed } 1940-1978 \text { then prescribe-burned one, two, } \\
\text { or three times in late spring or summer during } 1979-1984 \text {, with } 2-3 \text { years } \\
\text { between prescribed fires on units burned two or three times }{ }^{\ddagger}\end{array}$ \\
\hline Burn perimeter & 2 & 19.2 & $\begin{array}{l}\text { Not prescribe-burned; a mix of grazed }<19 \text {, grazed }>29 \text {, and prolonged rest } \\
\text { categories }\end{array}$ \\
\hline
\end{tabular}

*Range $11-18$ years.

'Range 30-36 years.

Table 2 presents detailed 1979-1984 fire treatment history for each unit.

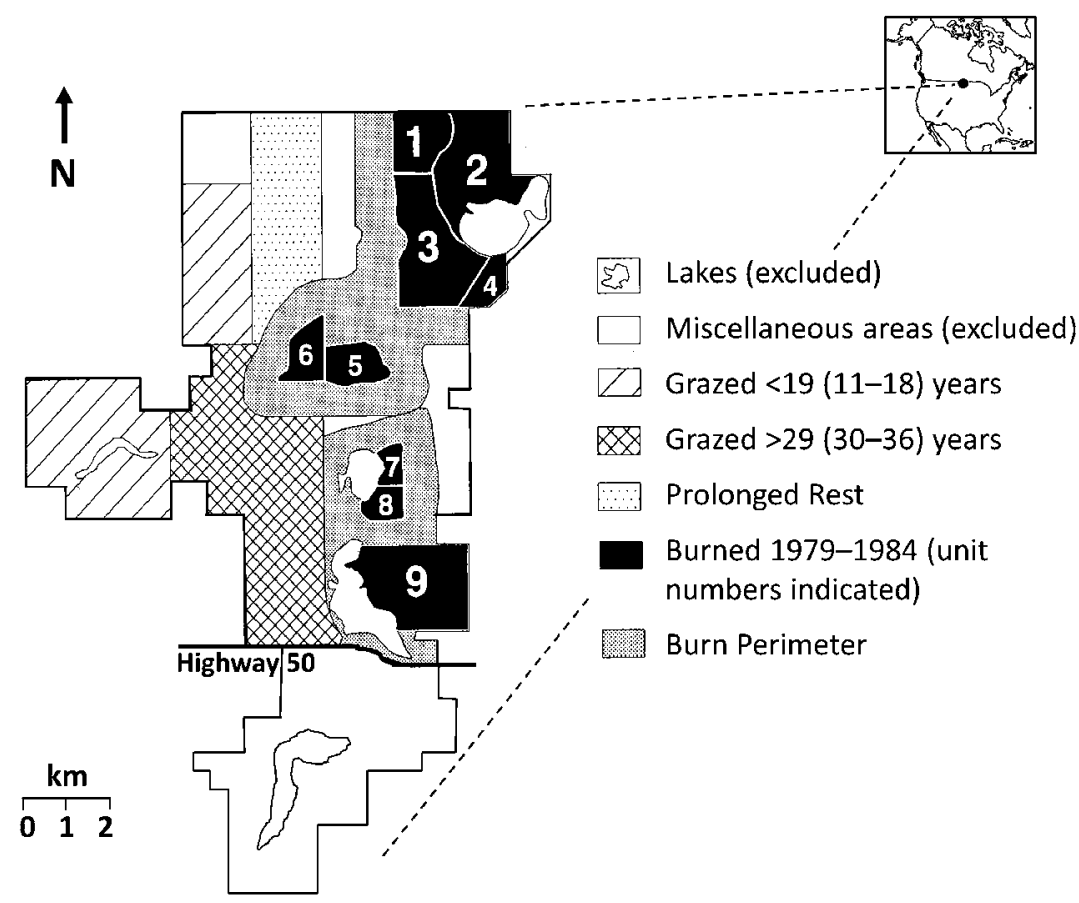

FIGURE 1. Location and management history of prairie management units on Lostwood National Wildlife Refuge in northwestern North Dakota as of 1981-1985, when density (individuals $/ \mathrm{km}^{2}$ ) of male Sharp-tailed Grouse (Tympanuchus phasianellus) displaying on leks in spring was documented annually on units of five management categories. These were compared to densities of lekking males documented on the respective units during 1961-1965. The refuge area south of Highway 50 was excluded from the comparison of densities as it was open to hunting of Sharp-tailed Grouse. Inset map (upper right) indicates the study area (black dot) in relation to North America's northern mixed-grass prairie region (grey shaded).

two units, respectively (Table 1). Our conclusions were thus limited. We considered, however, that tentative evidence of a treatment effect might be implied for a given management history category if $90 \%$ CIs around the respective 1961-1965 and 1981-1985 mean densities did not overlap. Moreover, our approach to assessing male Sharp-tailed Grouse density in relation to prescribed fire included counts of lekking males on all prescribed fire units each spring, such that in a given spring, residual vegetation was 
TABLE 2. Size, year of treatment, and thoroughness of burns on prairie management units treated by prescribed fire on Lostwood National Wildlife Refuge in northwestern North Dakota during June, July, or August, 1979-1984.

\begin{tabular}{|c|c|c|c|c|c|c|c|}
\hline \multirow{2}{*}{ Unit number } & \multirow{2}{*}{ Area $\left(\mathrm{km}^{2}\right)$} & \multicolumn{6}{|c|}{ Year } \\
\hline & & 1979 & 1980 & 1981 & 1982 & 1983 & 1984 \\
\hline 1 & 1.0 & $\mathrm{c}^{*}$ & & $\mathrm{c}$ & & $\mathrm{c}$ & \\
\hline 2 & 3.7 & & $\mathrm{~b}$ & & $\mathrm{c}$ & & \\
\hline 3 & 5.0 & & & $\mathrm{c}$ & & $\mathrm{c}$ & \\
\hline 4 & 0.5 & $\mathrm{a}$ & & $\mathrm{b}$ & & $\mathrm{c}$ & \\
\hline 5 & 0.9 & $\mathrm{c}$ & & & $\mathrm{a}$ & $\mathrm{b}$ & \\
\hline 6 & 1.0 & & & & $\mathrm{c}$ & & $\mathrm{b}$ \\
\hline 7 & 0.4 & & & & $\mathrm{c}$ & & \\
\hline 8 & 0.5 & & & & $\mathrm{c}$ & & $\mathrm{c}$ \\
\hline 9 & 3.8 & & & & $\mathrm{c}$ & & \\
\hline
\end{tabular}

*Approximate percentage of above-ground live and residual vegetation removed by prescribed fire: (a) 35-50\%; (b) 51-80\%; (c) $>80 \%$.

limited on units that had been burned the previous summer. This provides for a conservative picture of the species' response to prescribed fire because in the first spring after summer fires, vegetation on LNWR is relatively short and sparse (Madden et al. 1999), less than optimal for females seeking nest sites. Because male Sharp-tailed Grouse compete for space on leks near areas frequented by females seeking ideal nesting cover (Gratson 1988), lek attendance by males is likely to be reduced during the first spring after summer fires. We acknowledge that small numbers of male Sharp-tailed Grouse may not attend leks in some years or do so infrequently (Gratson et al. 1991) but believe this possibility would negligibly influence our conclusions.

During 1986-1993, following the initial prescribed fires, incrementally greater proportions of LNWR were treated by prescribed fire such that units lacking prescribed fire histories including burn perimeter became less and less available. This change hindered longer-term comparison of male Sharptailed Grouse density among management history categories. We could, however, assess landscape-level changes in abundance (i.e., total numbers) of lekking male Sharp-tailed Grouse across all of LNWR in relation to prescribed fire. For our second objective, we sought to examine abundance of lekking males in the first five-year period after 1985 during which $>50 \%$ of the refuge was treated with prescribed fire. We also sought a five-year period during which mean annual precipitation, from one year before the start to one year before the end of the period, was similar to that in the 1961-1965 baseline (40.2 cm) and 1981-1985 initial prescribed fire periods $(41.7 \mathrm{~cm})$. For a given year, we considered precipitation level in the previous year as a key potential confounding factor in our comparison because it can markedly influence survival of Sharp-tailed Grouse in general (Cartwright
1944). The years 1989-1993 met these two criteria (55-64\% of refuge burned; $40.0 \mathrm{~cm}$ mean annual precipitation during 1988-1992), except that an unnaturally severe wildfire burned a $22.7-\mathrm{km}^{2}$ unit of the refuge in August 1988. We considered the wildfire an anomaly because it occurred when there was an abnormally high buildup of residual vegetation combined with ambient temperature, relative humidity, fuel moisture, and windspeed conditions far exceeding bounds for conducting prescribed fires (U.S. Fish and Wildlife Service unpubl. data). The wildfire burned into the humus layer and in many places to mineral soil, removing all residual and live, aboveground herbaceous and woody vegetation except for $\sim 40 \%$ of tree-size Trembling Aspen and scant patches of Western Snowberry. Therefore, we replaced the following spring's (1989) count of lekking males with like data from spring 1987, the only year following prescribed fire treatment (July 1986) of the area, although total precipitation in the previous year (1986) was slightly greater $(45.7 \mathrm{~cm})$ than the 1988-1992 mean. Last, we considered the August 1988 wildfire to be, in effect, a 1989 prescribed fire with regard to its influence on residual vegetation and numbers of lekking male grouse the following spring.

We therefore consider the 1989-1993 period as a landscape-level prescribed fire period (hereafter the Landscape Fire period). In a similar vein, we hereafter refer to the 1961-1965 period, that neared the end of $\sim 60$ years of fire suppression, as the Fire Exclusion period, and the 1981-1985 years associated with initial prescribed fire treatments as the Initial Fire period.

During the mid-1980s, LNWR was partitioned into 20 "management blocks" (MBs) averaging 4.7 $\mathrm{km}^{2}$ in area $(\mathrm{SE}=1.0$, range $=0.6-22.7)$. To assess whether total abundance of lekking male Sharptailed Grouse on LNWR changed between any two 
of the three time periods, we first combined small $(<5$ $\mathrm{km}^{2}$ ), adjoining MBs into five MB groups composed of two to four MBs each. Each of five other "groups" were represented by one large MB. Thus, a total of $10 \mathrm{MB}$ groups were available to provide adequate sample sizes for a matched-pairs analyses of temporal change in abundance of lekking male grouse. We next summed the total number of lekking males in each MB group, for each year in each of the three time periods, then calculated the mean annual abundance of lekking males for each MB group by period. To test for a difference in total abundance between two given periods, we paired the periods' annual means for each MB group and used the non-parametric Wilcoxon matched-pairs signed-ranks test (Daniel 1990) to assess whether overall means of the paired observations differed. Specifically, we used a twotailed version of the test with $\alpha$ set at 0.1 to determine whether total abundance of lekking male Sharptailed Grouse differed between (1) the Fire Exclusion and Initial Fire periods, (2) Initial Fire and Landscape Fire periods, and (3) Fire Exclusion and Landscape Fire periods. A one-tailed test would seem appropriate based on knowledge that Sharp-tailed Grouse abundance can increase when prescribed fire is incorporated into the habitat disturbance regime (Kirsch and Kruse 1972; Kirsch et al. 1973). However, onetailed Wilcoxon tests performed with small sizes, as in our case (10 matched pairs), can result in incorrect $P$-values (Mundry and Fischer 1998), so we used the more conservative two-tailed approach. Before conducting the tests, we plotted distributions of the differences between pairs and found the distributions to be reasonably symmetrical, an assumption of the Wilcoxon signed-ranks test (Daniel 1990).

Finally, we categorized each MB by the number of prescribed fires (i.e., fire history) applied to it during 1979-1992, from none up to four (Figure 2). However, most area covered by two MBs in a three or four burns category also was treated with intensive, prolonged grazing by cattle during two and three (respectively) late spring-early summer seasons of the Landscape Fire period. So, we placed them in a unique fire history category named " 3 or 4 Burns plus Grazing" (3+G in Figure 2). The $22.7-\mathrm{km}^{2}$ unit that experienced a severe wildfire in August 1988 was placed in its own MB category, named "1 Burn plus 1 Wildfire" $(1+\mathrm{W})$, because the wildfire event distinguished it from other MBs; this MB also was unique due to its large size, nearly four times larger than any other. We used non-overlap of $90 \%$ CIs encompassing means as tentative evidence of differences in abundance of lekking male Sharp-tailed Grouse among fire history categories in different periods. We also calculated period-specific densities of lekking male Sharp-tailed Grouse for each fire history category.

\section{Results}

Based on non-overlapping 90\% CIs (Figure 3), the mean annual density of lekking male Sharp-tailed Grouse on prairie management units that were treated by prescribed fire during the Initial Fire period was more than double what it was on the same units $\sim 20$ years earlier, during the Fire Exclusion period. Meanwhile, densities of lekking males did not differ between the periods on rested, grazed, and burn perimeter units, based on substantial overlap among 90\% CIs (Figure 3).

Across all of LNWR, the mean annual abundance of lekking male Sharp-tailed Grouse did not differ be-

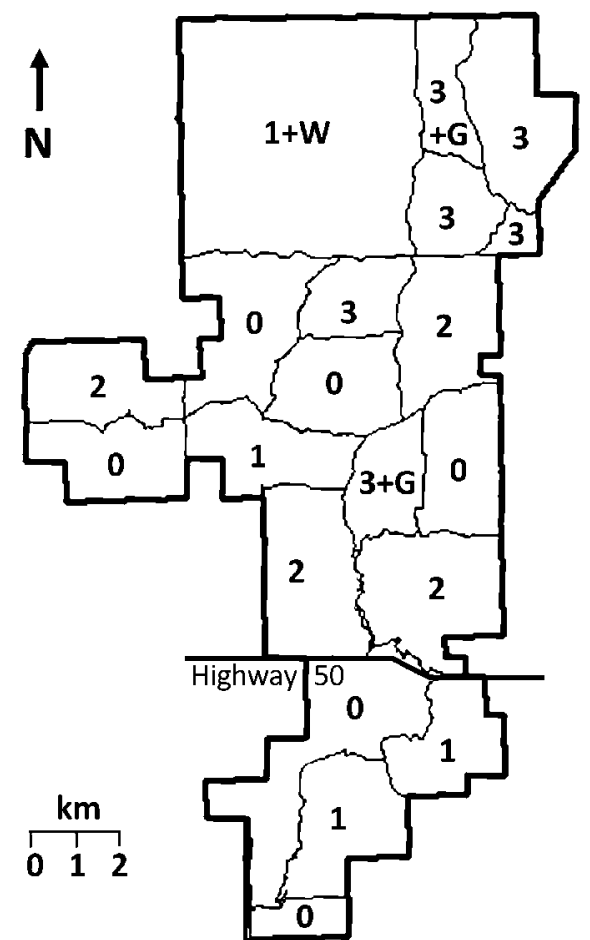

Prescribed fire history categories of Management Blocks (number of blocks in parentheses):

$\begin{array}{ll}\mathbf{0} & \text { 0 Burns (6) } \\ \mathbf{1} & \text { 1 Burn (3) } \\ \mathbf{1 + W} & \text { 1 Burn plus 1 Wildfire (1) } \\ \mathbf{2} & \text { 2 Burns (4) } \\ \mathbf{3} & \text { 3 or 4 Burns (4) } \\ \mathbf{3 + G} & \text { 3 or 4 Burns plus Grazing (2) }\end{array}$

FigUre 2. Number of prescribed fires applied during 19791992 on management blocks at Lostwood National Wildlife Refuge in northwestern North Dakota. Wildfires had been effectively suppressed on the area before 1979. Management block boundaries were designated during the mid-1980s. 


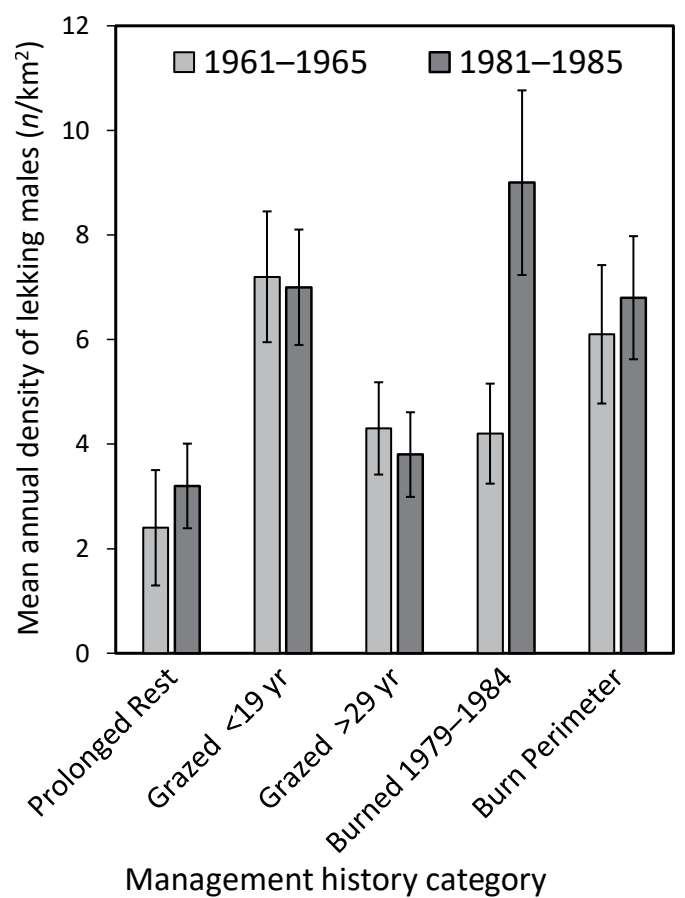

Figure 3. Mean annual densities (individuals $/ \mathrm{km}^{2}$ ) of lekking male Sharp-tailed Grouse (Tympanuchus phasianellus) at Lostwood National Wildlife Refuge in northwestern North Dakota during 1961-1965 and 1981-1985 on multiple prairie management units of each of five management history categories (see Table 1); density was assessed on the same units of each category during both time periods. After $\sim 60$ years of fire suppression, prescribed fire was re-introduced to the refuge during 1979-1984, specifically on units in the Burn 1979-1984 category. Error bars are 90\% CIs.

tween the Fire Exclusion and Initial Fire periods $\left(W^{+}\right.$ $=23.5, n=10, P=0.70$; Figure 4). However, mean annual abundance of lekking male Sharp-tailed Grouse across all of LNWR was significantly greater during the Landscape Fire period than during the Fire Exclusion $\left(W^{+}=7, n=10, P=0.04\right)$ and Initial Fire periods $\left(W^{+}=2, n=10, P=0.006\right.$; Figure 4$)$. A $32 \%$ increase in mean annual abundance from the Initial Fire to Landscape Fire periods coincided with a substantial rise in the percentage of LNWR treated by prescribed fire at least once, from $6.0-15.7 \%$ during 1979-1984 to $53.4-63.1 \%$ during 1987-1992 (Figure 4). Up to 1185 lekking males were recorded in one year (1992), representing an overall density of 12.6 males $/ \mathrm{km}^{2}$ (based on $94.2 \mathrm{~km}^{2}$ total refuge area excluding major lakes). Most of the increase in total numbers arose from MBs burned once or twice between 1979 and 1992 (Figure 5a). During this period, density of lekking males seemed consistently high across all categories of number of fires experienced (range of means $=9.7$ to 10.7 males $/ \mathrm{km}^{2}$; range of CIs, \pm 1.7 to \pm 2.7 ), except for the " 3 or 4 Burns plus Grazing" category, where no lekking males were detected, and the " 0 Burns" category (Figure 5b).

\section{Discussion}

Our case study of the re-introduction of fire to a large tract of NMPG deprived of fire for $>60$ years and associated changes in density and abundance of lekking male Sharp-tailed Grouse is unique for the NMGP region. It may well illustrate the species' marked capacity to respond to the reduction of trees and shrubs by prescribed fires in a prairie ecosystem, and to major perturbations in general. During the 1981-1985 Initial Fire period, the mean annual density of lekking males was about two-fold greater on prairie management units receiving initial prescribed fire treatments than on the same units during the Fire Exclusion period two decades earlier, when the units had been managed by prolonged rest or rest and grazing. This increase occurred even though the Initial Fire dataset included many counts of males on units treated by prescribed fire in previous summers. Scattered unburned patches of vegetation may have attracted nesting females to such areas; unburned "skips" comprised a mean of $14.5 \%$ of three units burned during 1982-1984 (Kruse and Piehl 1984). Moreover, the lack of change in male densities between the Fire Exclusion and Initial Fire periods on all but the burn units suggests that the increased density of lekking male Sharp-tailed Grouse on burn units can be attributed to the general growth in bird numbers on those units rather than just shifts in locations of males from other units.

In contrast with the markedly increased density of male Sharp-tailed Grouse between the Fire Exclusion and Initial Fire periods on management units in the burn category, we found no evidence of concurrent change in male density on units categorized as either prolonged rest, $<19$ years grazed, or $>29$ years grazed. Under the latter management regimes, however, densities likely would have declined during time intervals exceeding two decades, as trees and shrubs continued to displace grass- and forb-dominated prairie. Indeed, in the absence of fire for roughly six decades, much of the NMGP refuge had become aspen parkland, with some $2.59-\mathrm{km}^{2}$ sections having $>15$ aspen tree patches (Murphy 1993). In southern Manitoba, Berger and Baydack (1992) documented a severe decline in the number of Sharp-tailed Grouse leks as prairie gradually transformed into Trembling Aspen-dominated forest during only 21 years of fire suppression; on average, the birds abandoned a given lek if forest cover within $1 \mathrm{~km}$ exceeded $56 \%$. Tree-size Trembling Aspen cover at LNWR averaged far less, only about $0.6 \%$ in 1969 and $0.7 \%$ in 


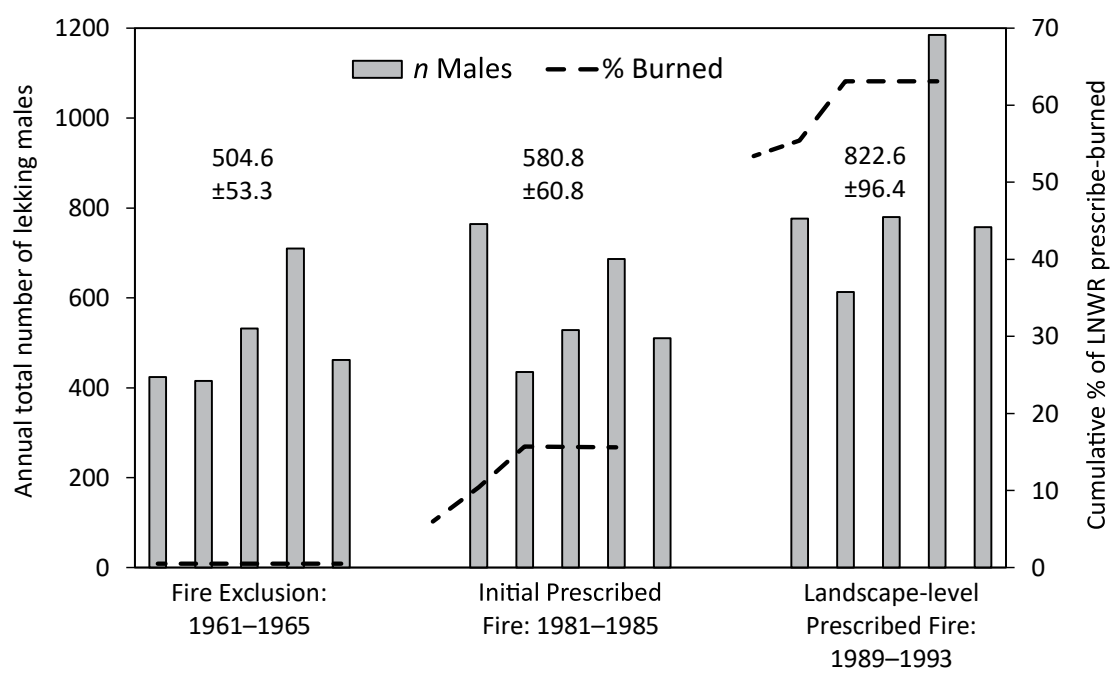

FigURE 4. Change in annual abundance, i.e., total number, of male Sharp-tailed Grouse (Tympanuchus phasianellus) attending leks in spring at Lostwood National Wildlife Refuge, northwestern North Dakota during three historic time periods in relation to percentage of the refuge treated by prescribed fire at least once beginning in 1979, after $\sim 60$ years of fire suppression. Prescribed fires were conducted during late spring through summer. Due to an artificially severe wildfire on a 22.7- $\mathrm{km}^{2}$ management block in August 1988, the 1989 count of lekking males was replaced by like data from 1987, following the management block's first prescribed fire in 1986 (see text). Above each five-year group of columns is the respective group mean $\pm 1 \mathrm{SE}$.

1985 (Figure 4 in Grant and Murphy [2005]). Thus, the near-complete removal of aspen trees at LNWR via burning or combinations of grazing and burning (Smith and Murphy 2007) probably contributed less to increases in male Sharp-tailed Grouse abundance than did the conversion of much shrub cover (mainly Western Snowberry and Silverberry) to grass-forb cover types via prescribed fire (Madden et al. 1999). Such a conversion has been critical in restoring other key members of the refuge's grassland bird community. For example, the endemic Sprague's Pipit (Anthus spragueii) and Baird's Sparrow (Ammodramus bairdii) were absent and rare, respectively, on two 90 -ha tracts rested and lightly grazed for $>40$ years but reappeared and increased after four prescribed fires were conducted during a $\sim 16$-year period. These changes coincided with a shift in grass-dominated cover from $45 \%$ to $84 \%$ and a $33 \%$ reduction in overall vegetation height and density (Murphy and Smith 2007).

The increase in Sharp-tailed Grouse density on management units undergoing initial prescribed fire treatments in our case study was consistent with a $32 \%$ increase in total abundance of males at the landscape scale during the Landscape Fire period, when $>50 \%$ of the refuge had been burned at least once. Historically, the fire return interval for the eastern, more mesic part of the NMGP that encompasses LNWR averaged roughly six years (Bragg 1995; Madden et al. 1999). A mosaic of manage- ment units under short ( $2-4$ years) and moderate (5-7 years) fire return intervals seems optimal for most native grassland bird species at LNWR (Madden et al. 1999). The heterogenous structure and general composition of vegetation in units managed under these fire return intervals (Madden et al. 1999, 2000) may be ideal for Sharp-tailed Grouse as well. Indeed, the mean annual density of lekking males during the Initial Fire period was high on units treated by prescribed fire even though most units were burned two to three times with only $1-2$ years between treatments. Although Sharp-tailed Grouse have a general affinity for frequent disturbance and early successional stages (Kirsch et al. 1973; Connelly et al. 1998), the consistently high mean annual densities of lekking males across MBs of all fire history categories (excluding MBs that also were intensively grazed; Figure 5b) during the Landscape Fire period, suggest that the bird's abundance in NMGP does not necessarily increase with increasing "fire experience" (sensu Madden et al. 1999), at least during 10- to 15year periods.

Conclusions about effects of a given fire return interval on the structure and general composition of NMGP - and thus on attractiveness of the habitat for Sharp-tailed Grouse-should be considered tentative, particularly if other types of defoliation treatments are applied between prescribed fires. The type, frequency, duration, and intensity of any such treatments likely influence effects of a given fire return 


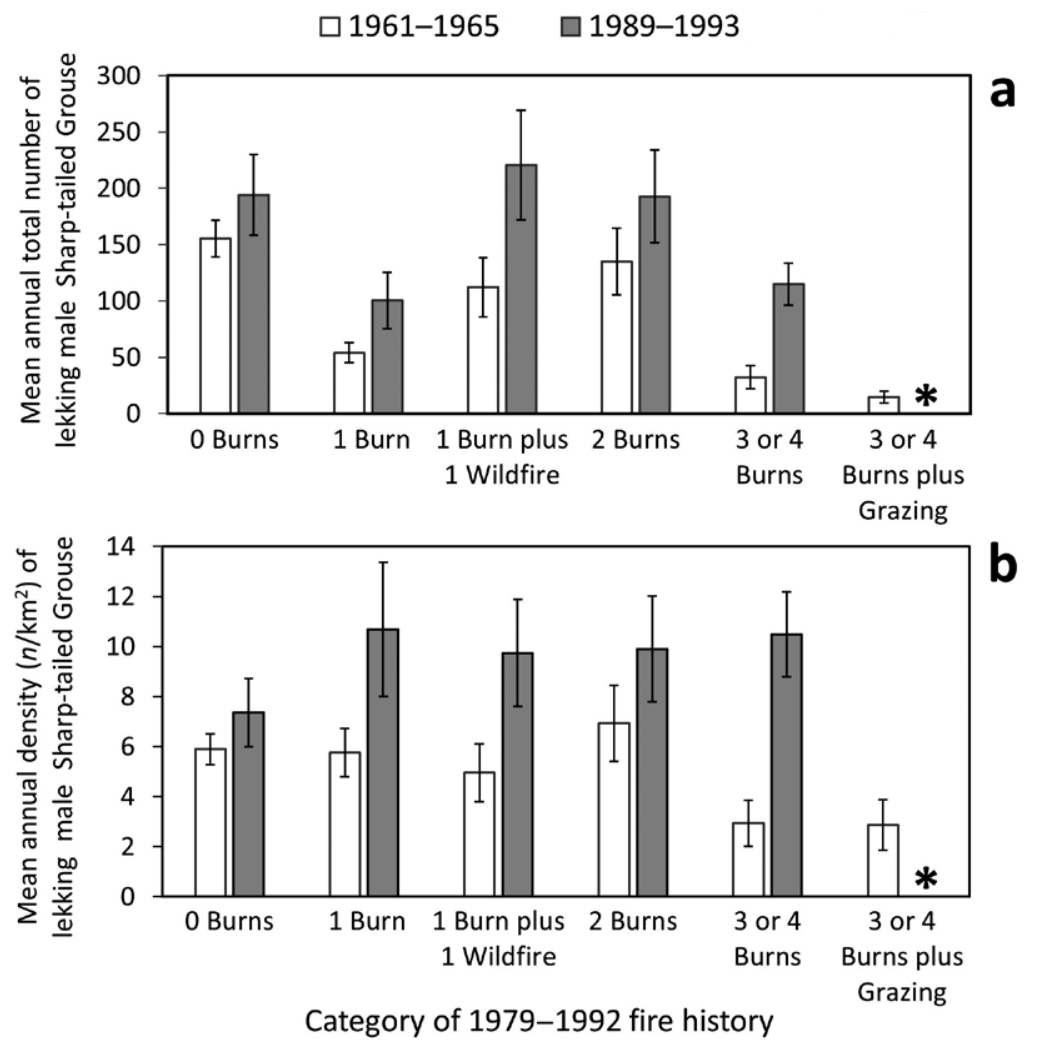

Figure 5. Mean annual abundance (i.e., total number of individuals, a) and density (i.e., number of individuals $/ \mathrm{km}^{2}$, b) of male Sharp-tailed Grouse (Tympanuchus phasianellus) attending leks in spring at Lostwood National Wildlife Refuge, northwestern North Dakota: (1) during 1961-1965, amid 60 years of fire suppression; and (2) during 1989-1993, by which time $>50 \%$ of the refuge area had been prescribe-burned at least once, beginning in 1979 . The refuge is divided into six categories of management blocks based on numbers of fires experienced during 1979-1992. Thus, values during 1961-1965 reflect abundance and density before fire was re-introduced to the refuge. Each category of fire history is represented by two to six management blocks except the "1 Burn plus 1 Wildfire" $(1+\mathrm{W})$ category, which is represented by a single but very large $\left(22.7 \mathrm{~km}^{2}\right)$ management block. Due to an artificially severe wildfire on this latter area in August 1988, the 1989 count of lekking males was replaced by like data from 1987, following the management block's first prescribed fire in 1986 (see text). In addition to having multiple prescribed fires, management blocks in the " 3 or 4 Burns plus Grazing" (3+G) category received intensive, prolonged grazing by cattle in spring and early summer for 2-3 years during 1988-1992, leaving little residual nesting cover for Sharp-tailed Grouse in subsequent springs. Error bars are $90 \%$ CIs. Asterisks indicate no lekking males detected.

interval on prairie vegetation in general, e.g., by reducing fuel loads (Engle and Bidwell 2001). Also, influences of various fire return intervals on vegetation structure and composition may be confounded by the presence of Smooth Brome (Bromus inermis Leysser) and Kentucky Bluegrass (Poa pratensis L.), two introduced, cool-season grass species that have become pervasive in much of the NMGP (Romo et al. 1990; Murphy and Grant 2005). These grasses appear to be increasing regardless of prairie management treatment history (Ellis-Felege et al. 2013; but see Kobiela et al. 2017), a change that may reduce the availability and attractiveness of cover for Sharptailed Grouse.
Our comparisons of Sharp-tailed Grouse density and abundance among the Fire Exclusion, Initial Fire, and Landscape Fire periods included some basic components of a before-after-control-impact (BACI) study design, but our overall case study was observational in nature and lacked robust replication. Ideally, a statistically valid experimental design with replication across a more extensive landscape would be used to distinguish effects of habitat management on Sharp-tailed Grouse from confounding, non-management, factors, e.g., precipitation extremes. Aldridge et al. (2004) attempted this in an aspen parkland landscape. Regardless, long-term monitoring of Sharptailed Grouse abundance at LNWR enables passive 
adaptive management of the species' NMGP habitat (Aldridge et al. 2004).

\section{Acknowledgements}

We dedicate this paper to the memory of three northern prairie and prairie grouse management experts: Michael Gratson, Leo Kirsch, and Arnie Kruse. During 1961-1965, counts of lekking male Sharptailed Grouse at Lostwood National Wildlife Refuge were conducted by Merrill Hammond, Ned Peabody, and Don White. Bob Danley and Ken Maruskie assisted us with lek counts during the 1990s. Discussions with Ryan Nielson (Eagle Environmental Inc.) enhanced our approach to data analyses. We thank Todd Grant, two anonymous reviewers, and Associate Editor Jenn Foote for many comments that markedly improved our manuscript. Findings and conclusions in this article are those of the authors and do not necessarily represent views of the United States Fish and Wildlife Service.

\section{Literature Cited}

Aldridge, C.L., M.S. Boyce, and R.K. Baydack. 2004. Adaptive management of prairie grouse: how do we get there? Wildlife Society Bulletin 32: 92-103. https://doi. org/10.2193/0091-7648(2004)32[92:amopgh]2.0.co;2

Barker, W.B., and W.C. Whitman. 1988. Vegetation of the Northern Great Plains. Rangelands 10: 266-272. Accessed 13 May 2019. https://journals.uair.arizona.edu/ index.php/rangelands/article/viewFile/10975/10248.

Berger, R.P., and R.K. Baydack. 1992. Effects of aspen succession on Sharp-tailed Grouse, Tymphanuchus phasianellus, in the interlake region of Manitoba. Canadian Field-Naturalist 106: 185-191. Accessed 13 May 2019. https://biodiversitylibrary.org/page/34347405.

Bragg, T.B. 1995. Climate, soils and fire: the physical environment of North American grasslands. Pages 49-81 in The Changing Prairie. Edited by K.H. Keeler and A. Joern. Oxford University Press, New York, New York, USA.

Caldwell, P.J. 1976. Energetic and population consideration of Sharp-tailed Grouse in the Aspen Parkland of Canada. Ph.D. thesis, Kansas State University, Manhattan, Kansas, USA.

Cartwright, B.W. 1944. The "crash" decline in Sharptailed Grouse and Hungarian Partridge in western Canada and the role of the predator. Transactions of the North American Wildlife Conference 9: 324-329.

Connelly, J.W., M.W. Gratson, and K.P. Reese. 1998. Sharp-tailed Grouse (Tympanuchus phasianellus), version 2.0. In The Birds of North America. Edited by A.F. Poole and F.B. Gill. Cornell Lab of Ornithology, Ithaca, New York, USA. https://doi.org/10.2173/bna.354

Daniel, W.W. 1990. Applied Non-parametric Statistics. PWS-Kent, Boston, Massachusetts, USA.

Drummer, T.D., R.G. Corace, and S.J. Sjogren. 2011. Sharp-tailed Grouse lek attendance and fidelity in upper Michigan. Journal of Wildlife Management 75: 311-318. https://doi.org/10.1002/jwmg.42

Ellis-Felege, S.N., C.S. Dixon, and S.D. Wilson. 2013.
Impacts and management of invasive cool-season grasses in the Northern Great Plains: challenges and opportunities for wildlife. Wildlife Society Bulletin 37: 510-516. https://doi.org/10.1002/wsb.321

Engle, D.M., and T.G. Bidwell. 2001. The response of central North American prairies to seasonal fire. Journal of Range Management 54: 2-10. https://doi.org/10.2458/azu_ jrm_v54i1_engle

Grant, T.A., E. Madden, and G.B. Berkey. 2004. Tree and shrub invasion in northern mixed-grass prairie: implications for breeding grassland birds. Wildlife Society Bulletin 32: 807-818. https://doi.org/10.2193/0091-7648 (2004)032[0807:tasiin]2.0.co;2

Grant, T.A., and R.K. Murphy. 2005. Changes in woodland cover on prairie refuges in North Dakota, USA. Natural Areas Journal 25: 359-368.

Gratson, M.W. 1988. Spatial patterns, movements, and cover selection by Sharp-tailed Grouse. Pages 158-192 in Adaptive Strategies and Population Ecology of Northern Grouse. Edited by A.T. Bergerud and M.W Gratson. University of Minnesota Press, Minneapolis, Minnesota, USA.

Gratson, M.W., G.K. Gratson, and A.T. Bergerud. 1991. Male dominance and copulation disruption do not explain variance in male mating success on Sharp-tailed Grouse (Tympanuchus phasianellus) leks. Behaviour 118: 187-213. https://doi.org/10.1163/156853991x00283

Kirsch, L.M. 1956. Spring grouse census and habitat inventory methods. U.S. Fish and Wildlife Service, Wildlife Management Series Number 13.

Kirsch, L.M., A.T. Klett, and H.W. Miller. 1973. Land use and prairie grouse population relationships in North Dakota. Journal of Wildlife Management 37: 449-453. https://doi.org/10.2307/3800307

Kirsch, L.M., and A.D. Kruse. 1972. Prairie fires and wildlife. Tall Timbers Fire Ecology Conference 12: 289303.

Kobiela, B., J. Quast, C. Dixon, and E.S. DeKeyser. 2017. Targeting introduced species to improve plant community composition on USFWS-managed prairie remnants. Natural Areas Journal 37: 150-161. https://doi.org/ 10.3375/043.037.0204

Kruse, A.D., and J.L. Piehl. 1984. The impact of prescribed burning on ground-nesting birds. Proceedings of the North American Prairie Conference 9: 153156. Accessed 13 May 2019. http://digicoll.library.wisc. edu/cgi-bin/EcoNatRes/EcoNatRes-idx?type=article\& did=EcoNatRes.NAPC09.AKruse\&id=EcoNatRes. NAPC09\&isize $=M$.

Madden, E.M., A.J. Hansen, and R.K. Murphy. 1999. Influence of prescribed fire history on habitat and abundance of passerine birds in northern mixed-grass prairie. Canadian Field-Naturalist 113: 627-640. Accessed 13 May 2019. https://biodiversitylibrary.org/page/3423 5497.

Madden, E.M., R.K. Murphy, A.J. Hansen, and L. Murray. 2000. Models for guiding management of prairie bird habitat in northwestern North Dakota. American Midland Naturalist 144: 377-393. https://doi.org/10.1674/00 03-0031(2000)144[0377:mfgmop]2.0.co;2

Moyles, D.L.J. 1981. Seasonal and daily use of plant com- 
munities by Sharp-tailed Grouse (Pedioecetes phasianellus) in the parklands of Alberta. Canadian FieldNaturalist 95: 287-291. Accessed 13 May 2019. https:// www.biodiversitylibrary.org/page/28061990.

Mundry, R., and J. Fischer. 1998. Use of statistical programs for nonparametric tests of small samples often leads to incorrect values: examples from animal behavior. Animal Behavior 6: 256-259. https://doi.org/10. 1006/anbe.1998.0756

Murphy, R.K. 1993. History, nesting biology, and predation ecology of breeding raptors in the Missouri Coteau of northwestern North Dakota. Ph.D. thesis, Montana State University, Bozeman, Montana, USA. Accessed 13 May 2019. https://scholarworks.montana. edu/xmlui/bitstream/handle/1/7252/31762102084736. pdf;sequence $=1$.

Murphy, R.K., and T.A. Grant. 2005. Land management history and floristics in mixed-grass prairie, North Dakota, USA. Natural Areas Journal 25: 351-358.

Murphy, R.K., and K.A. Smith. 2007. Long-term trends in abundance of breeding songbirds during restoration of northern mixed-grass prairie. Transactions of the North American Prairie Conference 20: 359-370. Accessed 13 May 2019. https://digitalcommons.unl.edu/ usfwspubs/79/.

Romo, J.T., P.L. Grilz, and E.A. Driver. 1990. Invasion of the Canadian prairies by an exotic perennial. Blue Jay 48: 131-135.

Smith, K.A., and R.K. Murphy. 2007. Burning and grazing regime decimates Quaking Aspen in a northern mixed-grass prairie (North Dakota). Ecological Restoration 25: 63-64.

U.S. Fish and Wildlife Service. 1998. Lostwood National Wildlife Refuge Comprehensive Conservation Plan. U.S. Fish and Wildlife Service, Mountain-Prairie Region, Denver, Colorado, USA. Accessed 13 May 2019. https:// www.fws.gov/mountain-prairie/refuges/completed PlanPDFs_F-L/1st_1998_ccpfinal_all.pdf.

U.S. Soil Conservation Service. 1975. Field technical guide. U.S. Department of Agriculture, Soil Conservation Service, Bismarck, North Dakota, USA.

Received 27 August 2018

Accepted 8 December 2019 